\title{
PRELIMINARY DATA ON THE ECOLOGICAL REQUIREMENTS OF THE INVASIVE SPINY-CHEEK CRAYFISH IN THE LOWER DANUBE
}

\author{
Mălina PIRVU * and Angheluţă VĂDINEANU ** \\ * West University, Faculty of Chemistry-Biology-Geography, Department of Biology-Chemistry, \\ Pestalozzi Street 16A, Timişoara, Romania, RO-300315, malina.pirvu@e-uvt.ro, \\ malinadumbrava@yahoo.com \\ ** University of Bucharest, Faculty of Biology, Department of Systems Ecology and Sustainability, \\ Splaiul Independenţei Street 91-95, Bucharest, Romania, RO-76201, anvadi@bio.unibuc.ro
}

DOI: 10.1515/trser-2015-0038

KEYWORDS: Orconectes limosus, expansion, tributaries, water quality, Romania.

\begin{abstract}
Water quality and properties of the riverbed often shape the community structure of aquatic ecosystems, occasionally sustaining the expansion of non-native species. This study aims to provide preliminary data on the ecological preferences of the invasive species Orconectes limosus, its control, and the protection of the native stock is an European priority. In order to assess the species ability to colonize small river systems, relevant tributaries in the invaded Danube sector were monitored. Statistical test indicates a preference for deep and warm rivers, low water velocity and also high concentrations of calcium.

RÉSUMÉN: Los datos preliminares sobre las exigencias ecológicas del cangrejo invasivo (espinoso-mejilla) en el bajo Danubio.

La calidad del agua y las propiedades del cauce del río a menudo dan forma a la estructura de la comunidad de ecosistemas acuáticos y, ocasionalmente, sostienen la expansión de especies no-nativas. El objetivo de este estudio es proporcionar datos preliminares sobre las preferencias ecológicas de la especie invasiva Orconectes limosus, su control y protección de la población nativa siendo una prioridad europea. A fin de evaluar la habilidad de la especie en colonizar pequeños sistemas fluviales, afluentes relevantes en el sector invadido del Danubio fueron monitorizados. El test estadístico indicó la preferencia hacía ríos profundos y cálidos, con baja velocidad del agua y también altas concentraciones de calcio.

REZUMAT: Date preliminare asupra cerinţelor ecologice ale speciei invazive racul dungat pe cursul inferior al Dunării.

Calitatea apei și caracteristicile albiei modelează frecvent structura comunităților ecosistemelor acvatice, ocazional susținând expansiunea speciilor non-native. Prezentul studiu are drept scop furnizarea de date preliminare cu privire la preferințele ecologice ale speciei invazive Orconectes limosus, controlul acesteia și protecția stocului nativ fiind o prioritate la nivel european. În vederea evaluării capacităţii speciei de a coloniza sisteme acvatice de tipul râurilor de talie mică au fost monitorizați anumiţi afluenți ai Dunării în sectorul deja populat de specia țintă. Analizele statistice sugerează preferința acesteia pentru apele adânci și calde, cu viteză de curgere redusă și concentrații ridicate de calciu.
\end{abstract}




\section{INTRODUCTION}

The invasive species represent one of the most serious threats to global biodiversity due to their successful competivity and their major impact on the local native aquatic communities (Galil, 2007; Clavero et al., 2009; Peay and Füreder, 2011). The uncontrolled introduction of non-indigenous crayfish species (NICS) played a fundamental role in the current distribution of the indigenous crayfish species (ICS) (MEA, 2012). NICS rapid spread (Diéguez-Uribeondo, 2006; Gherardi, 2006; Souty-Grosset et al., 2006) caused significant economic losses (EC, 2008; EC, 2012).

Five ICS reside in Europe, namely Astacus astacus, A. leptodactylus and A. pachypus, respectively Austropotamobius torrentium and A. pallipes (Holdich et al., 2010). The introduction of NICS is known for commercial purposes starting in the nineteenth century, being identified more than ten species (Holdich et al., 2010).

In Romania, there have been three reported ICS: Astacus astacus, A. leptodactylus and Austropotamobius torrentium (Băcescu, 1967; Pârvulescu, 2010). Also, since 2008, the presence of Orconectes limosus (Rafinesque, 1817) has been confirmed for the first time in the Danube River (Pârvulescu et al., 2009). O. limosus shows tolerance towards the habitat conditions and rapid life cycle, being also the carrier of Aphanomyces astaci Schikora 1906, a disease to which native species do not have resistance (Unestam, 1969; Lindqvist and Huner, 1999; Söderhäll and Cerenius, 1999). The spread of this species was demonstrated in large aquatic habitats (Buřič et al., 2009; Panov et al., 2009), but its ability to invade small rivers and streams is still poorly documented (Petrusek et al., 2006). In its original habitats this species usually lives in small streams (McAlpine et al., 1991). The contact between this species and A. astacus and A. torrentium has not been reported so far in Romania.

This study aimed to provide preliminary data on the ecological limitations of O. limosus in small tributaries, with the goal of sensitive A. astacus and A. torrentium long term conservation success.

\section{MATERIAL AND METHODS \\ Crayfish capture}

The sampling sites are geographically located in the "Iron Gates" Nature Park (PM, 2010). To assess the specific colonizing ability of O. limosus in small river systems, 10 sampling sites were surveyed, corresponding to eight tributaries which are flowing in the invaded Danube sector: Eșelnița (S1), Mraconia (S2), Liubotina (S3), Tisovița (S4), Sirinia (S5), Berzasca downstream (S6) and upstream (S7), Gornea downstream (S8) and upstream (S9), Radimna (S10). Subsequently, two tributaries were monitored: Gornea (SS1) and Berzasca (SS2) (Fig. 1) using the index of catch per unit effort (CPUE) (Paaver and Hurt, 2009), defined by the number of crayfish individuals captured on a river stretch of $100 \mathrm{~m}$ length. For SS1 and SS2 a transect method was used (Sîrbu and Benedek, 2004) by dividing the studied sector into 13 equal sections for SS1, and six sections for SS2, respectively. The transects were distributed both in the invaded and non-invaded river sectors.

The sampling was carried out seasonally in three successive years between 2011 and 2013. In the case of SS1 and SS2 tributaries, data collection was carried out in the summer and autumn seasons corresponding to the same period. 


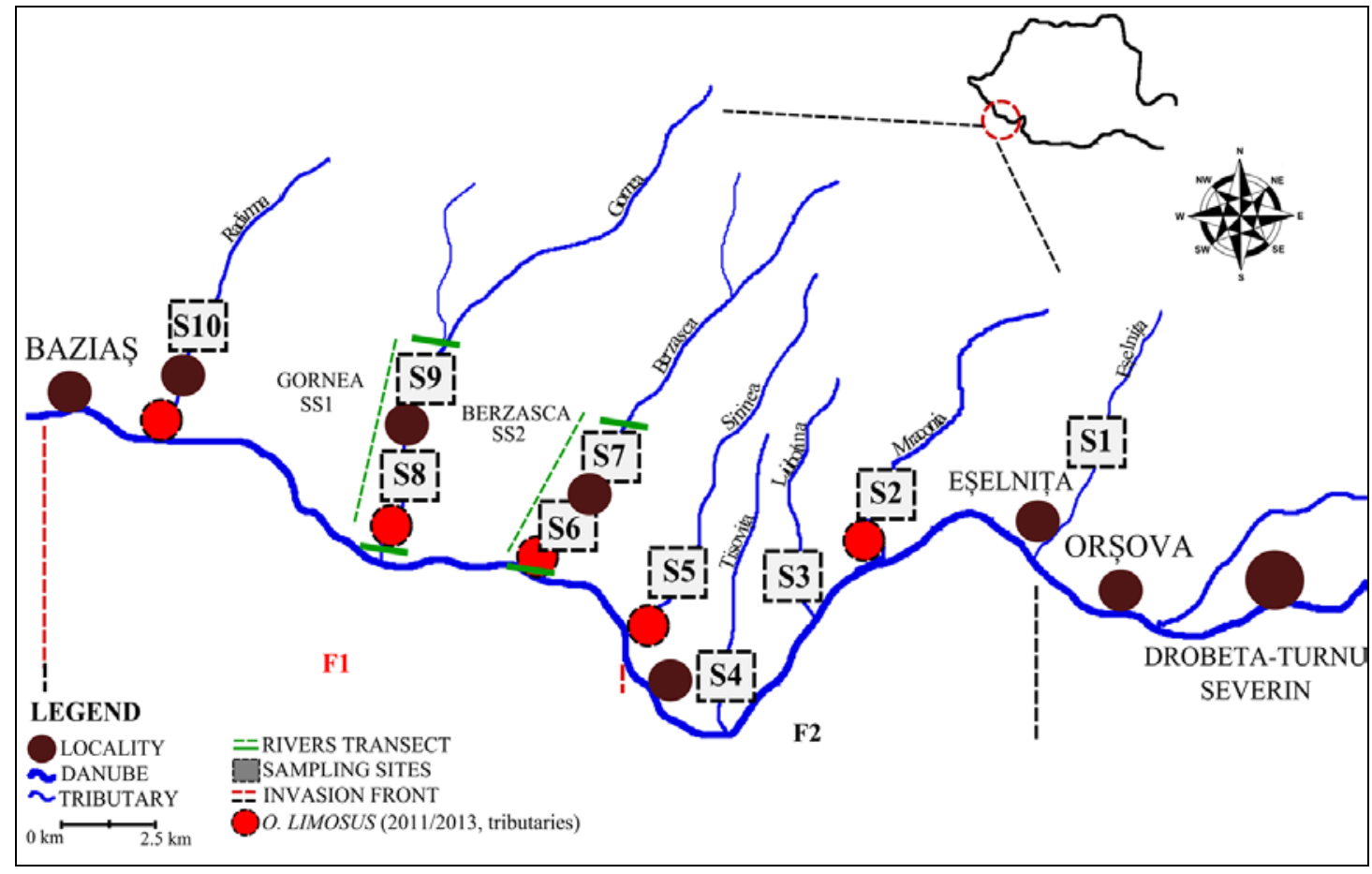

Figure 1: Sampling sites in the Baziaș-Orșova Danube sector, 2011-2013.

\section{Physical and chemical water parameters}

In order to draw an overall picture of the preferences of the species O. limosus, we measured the following water parameters: average width and depth of the bed/water; water velocity $(\mathrm{m} / \mathrm{s})$; dissolved oxygen $(\mathrm{mg} / \mathrm{l})$; conductivity $(\mu \mathrm{S} / \mathrm{cm})$; and $\mathrm{pH}$ and water temperature $\left({ }^{\circ} \mathrm{C}\right)$. The velocity of the water corresponding to each transect was determined by establishing the average value resulting from five readings per site using the floating object method described by Boyer (1964). The content of dissolved oxygen, conductivity, $\mathrm{pH}$, and water and air temperature were determined using Hach-Lange HQ40D multiparameter as the average of five readings per site.

The following chemical parameters of the water were also measured: nitrite $\left(\mathrm{N}-\mathrm{NO}_{2}\right)$, nitrate $\left(\mathrm{N}-\mathrm{NO}_{3}\right)$, phosphate $\left(\mathrm{P}^{-} \mathrm{PO}_{4}{ }^{3-}\right)$, ammonium $\left(\mathrm{N}^{-} \mathrm{NH}_{4}{ }^{+}\right)(\mathrm{mg} / \mathrm{l})$, total hardness $\left({ }^{\circ} \mathrm{dH}\right)$ calcium $\left(\mathrm{Ca}^{2+}\right)$ and magnesium $\left(\mathrm{Mg}^{2+}\right)(\mathrm{mg} / \mathrm{l})$. To determine these parameters, one reading per site was performed using a HACH-Lange DR2800 spectrophotometer.

\section{Statistical analyses}

The annual average values corresponding to the water parameters were computed. The non-parametric Mann-Whitney test was used in order to compare the differences in the physical-chemical parameters among the sites where the species was present or absent. The test was considered significant for p-values lower than 0.05. Box-plots were further used to reflect the potential ecological preferences of the species $O$. limosus in relation to its presence/absence. We showed this representation exclusively for $\mathrm{p}$-values $\leq 0.05$, respectively for those parameters for which significant differences were established during the entire study. Statistical analyses were performed using Statistica 7. 


\section{RESULTS AND DISCUSSION}

During this study 488 adult and juvenile individuals of $O$. limosus were captured, of which 103 from SS1 and 385 from SS2. Data processing was performed according to the annual change of the species invasion front on the Danube River as follows: summer 2011 spring 2012 period the invaded sector of Danube F1 included three tributaries corresponding to a number of two sites where the species was present $(\mathrm{S6}, \mathrm{S} 8)$ and three sites where it was absent (S7, S9-10). The sites located in the control area were not taken into account (S1-4): during summer 2012 - spring 2013 period, the invaded sector of Danube F2 included eight tributaries corresponding to four sites with presence (S2, S5-6, S8) and six with absence (S1, S3-4, S7, S9-10) (Fig. 1).

Table 1: Mann-Whitney results of the physico-chemical parameters over the presence/absence sites for the species O. limosus, 2011-2013.

\begin{tabular}{|l|c|c|}
\hline \multicolumn{1}{|c|}{ Physico-chemical parameters } & $2011-2012$ & $2012-2013$ \\
\hline average width & \multicolumn{2}{|c|}{ p-level } \\
\hline average depth & 0.137 & 0.505 \\
\hline water temperature & 0.008 & 0.016 \\
\hline water velocity & 0.000067 & 0.036 \\
\hline oxygen content & 0.371 & 0.009 \\
\hline $\mathrm{pH}$ & 0.557 & 0.190 \\
\hline conductivity & 0.867 & 0.615 \\
\hline $\mathrm{N}_{\mathrm{NO}}$ & 0.175 & 0.693 \\
\hline $\mathrm{N}-\mathrm{NO}_{3}$ & 0.063 & 0.193 \\
\hline phosphate & 0.084 & 0.547 \\
\hline ammonium & $\mathbf{0 . 0 4 6}$ & 0.155 \\
\hline total hardness & 0.221 & 0.771 \\
\hline $\mathrm{Ca}$ & 0.076 & 0.730 \\
\hline $\mathrm{Mg}$ & $\mathbf{0 . 0 2 3}$ & $\mathbf{0 . 0 4 1}$ \\
\hline
\end{tabular}

Table 2: Mann-Whitney results of the physico-chemical parameters over the presence/absence SS1 and SS2 transects for the species O. limosus, 2011-2013.

\begin{tabular}{|l|c|c|}
\hline \multicolumn{1}{|c|}{ Physico-chemical parameters } & SS1 & SS2 \\
\hline average width & \multicolumn{2}{|c|}{ p-level } \\
\hline average depht & 0.132 & 0.200 \\
\hline water temperature & 0.021 & 0.003 \\
\hline water velocity & 0.004 & 0.0005 \\
\hline oxygen content & 0.0001 & 0.022 \\
\hline $\mathrm{pH}$ & 0.041 & 0.113 \\
\hline conductivity & 0.445 & 0.071 \\
\hline $\mathrm{N}_{\mathrm{NO}}$ & 0.464 & 0.403 \\
\hline $\mathrm{N}-\mathrm{NO}_{3}$ & 0.289 & 0.606 \\
\hline phosphate & 0.722 & 0.468 \\
\hline ammonium & 0.082 & 1.000 \\
\hline total hardness & 0.428 & 0.808 \\
\hline $\mathrm{Ca}$ & 0.081 & 0.301 \\
\hline $\mathrm{Mg}$ & 0.007 & 0.003 \\
\hline
\end{tabular}


The Mann-Whitney test shows the differences in the physical-chemical parameters among the sites were the species was present or absent, the results being presented according to tables 1 and 2. In the case of the eight tributaries in which the presence or absence of the species $O$. limosus was considered, significant differences were obtained for parameters such as river depth and water temperature, along with the concentration of calcium. The phosphate concentration and the water velocity remained below the significance level for the period 2011-2012 and 2012-2013, respectively (Tab. 1). For SS1 and SS2, significant differences were found corresponding to the river depth, water temperature, and velocity, along with calcium and dissolved oxygen, with the exception that the last parameter was found significant exclusively for SS1 (Tab. 2).

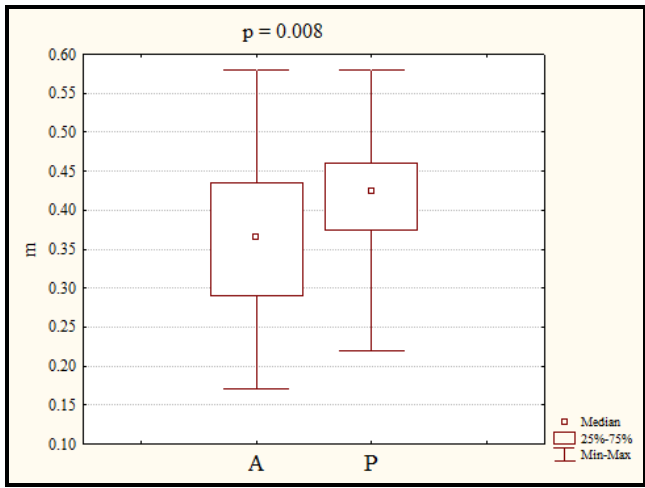

Figure 2a: Box-plots showing the average annual values of water depth (m) corresponding to the presence (P)/absence (A) of the species O. limosus, 2011-2012 (a).

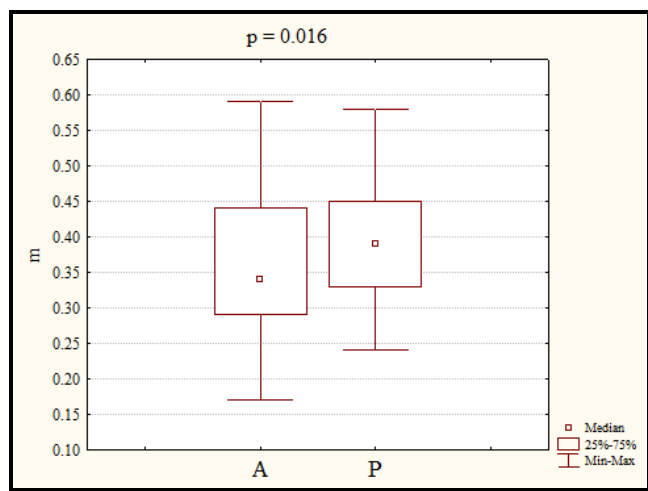

Figure 2b: Box-plots showing the average annual values of water depth (m) corresponding to the presence (P)/absence (A) of the species O. limosus, 2012-2013.

Considering all eight tributaries, the box-plots indicate the preference for deep river systems and warm water temperature (Figs. 2 and 3) as well as a high concentration of calcium (Fig. 4). The pattern is similar for SS1 and SS2 with significant differences for all three parameters (Figs. 5, 6 and 8). p-values $\leq 0.05$ were established also in terms of the water velocity indicating a preference for its lowest values (Tab. 1, Fig. 7), similarly with the pattern for the eight tributaries, but only in 2012-2013 (Tab. 2). The species particularly inhabits aquatic habitats with ecological characteristics different from those of small streams or springs, being encountered in the last two categories particularly in the downstream area (Aklehnovich and Razlutskij, 2013; Petrusek et al., 2006). 


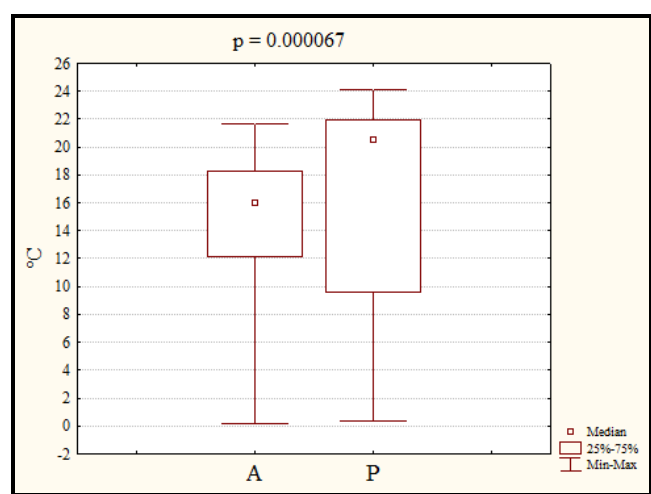

Figure 3a: Box-plots showing the average annual values of water temperature $\left({ }^{\circ} \mathrm{C}\right)$ corresponding to the presence (P)/absence (A) of the species O. limosus, 2011-2012.

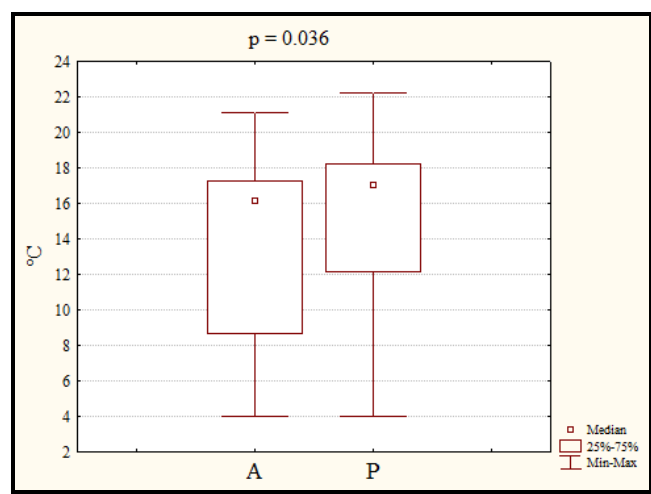

Figure 3b: Box-plots showing the average annual values of water temperature $\left({ }^{\circ} \mathrm{C}\right)$ corresponding to the presence (P)/absence (A) of the species O. limosus, 2012-2013 (b).

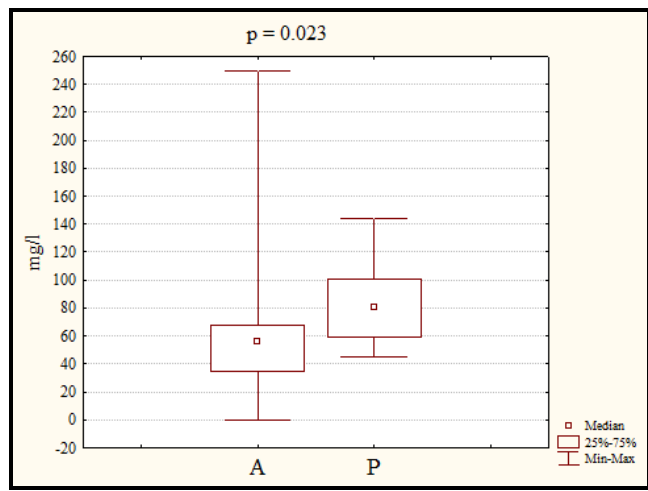

Figure 4a: Box-plots showing the average annual values of calcium (mg/l) corresponding to the presence (P)/absence (A) of the species O. limosus, 2011-2012. 


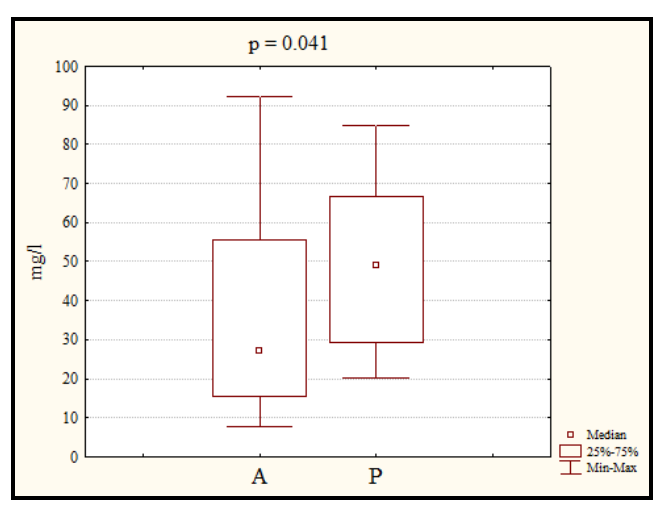

Figure 4b: Box-plots showing the average annual values of calcium (mg/l) corresponding to the presence (P)/absence (A) of the species O. limosus, 2012-2013.

In the habitats of origin, $O$. limosus is known to occupy a variety of aquatic ecosystems, with preference for those with low water velocity and substrate consisting mainly of sand and silt deposits (Ortmann, 1906). However, Aklehnovich and Razlutskij (2013) reported its presence both in lakes and rivers, the latter being the channels with muddy and hard substrate (rocks, stones, gravel).

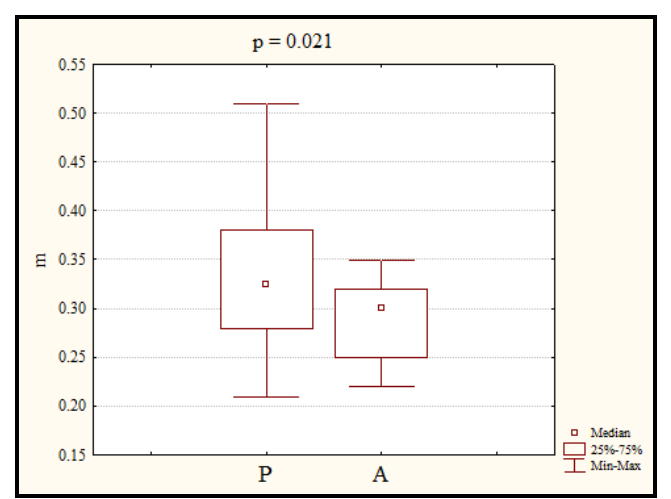

Figure 5a: Box-plots showing the average annual values of water deph $(\mathrm{m})$ corresponding to the presence (P)/absence (A) of the species O. limosus in SS1 2011-2013.

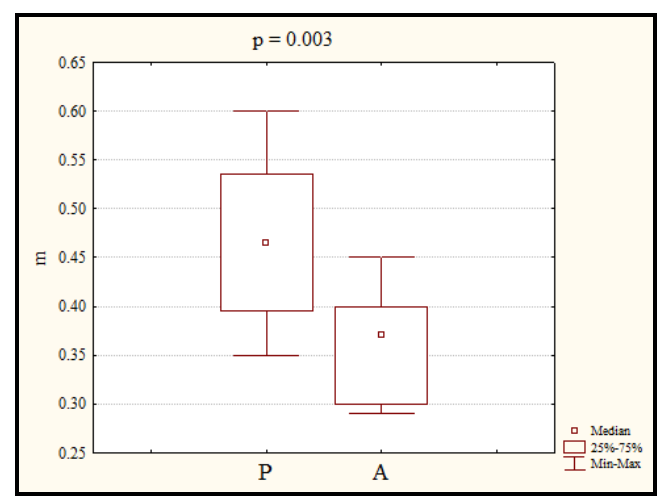

Figure 5b: Box-plots showing the average annual values of water deph (m) corresponding to the presence (P)/absence (A) of the species O. limosus in SS2, 2011-2013. 


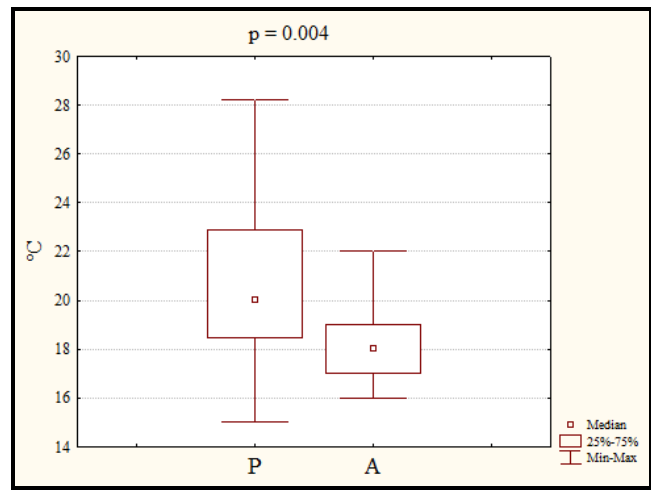

Figure 6a: Box-plots showing the average annual values of water temperature $\left({ }^{\circ} \mathrm{C}\right)$ corresponding to the presence (P)/absence (A) of the species O. limosus in SS1, 2011-2013.

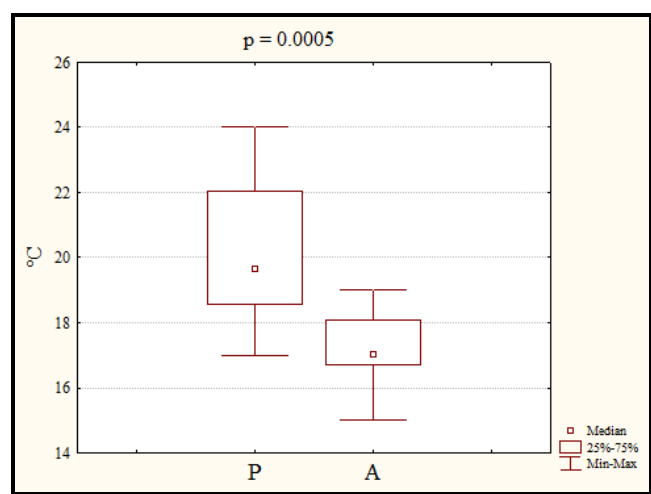

Figure 6b: Box-plots showing the average annual values of water temperature $\left({ }^{\circ} \mathrm{C}\right)$ corresponding to the presence (P)/absence (A) of the species O. limosus in SS2, 2011-2013.

In the case of the chemical water parameters, a certain pattern of preference was not identified with the exception of calcium, suggesting a potential preference for its higher values (Figs. 4 and 8). An explanation can be found in the calcium need of crustaceans in various important physiological processes as well as that of moulting (Ueno and Mizuhira, 1984).

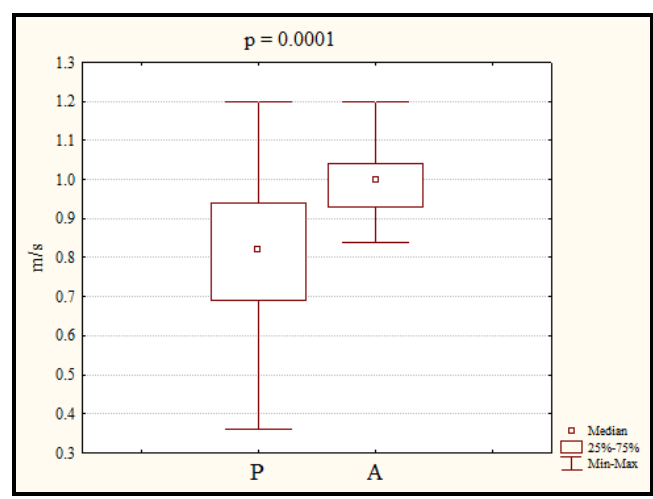

Figure 7a: Box-plots showing the average annual values of water velocity $(\mathrm{m} / \mathrm{s})$ corresponding to the presence (P)/absence (A) of the species O. limosus in SS1, 2011-2013. 


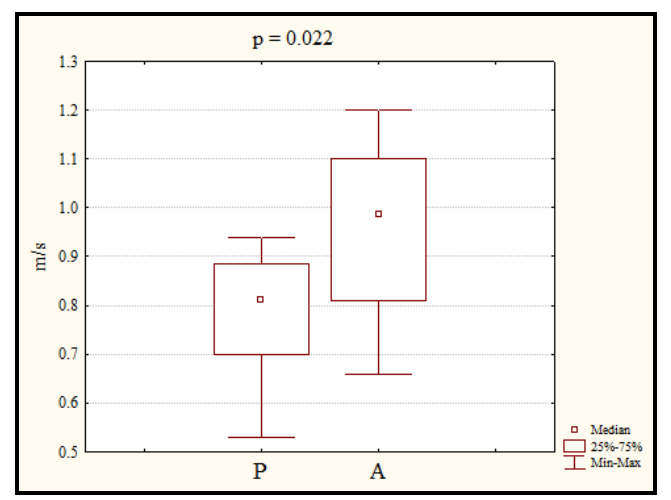

Figure 7b: Box-plots showing the average annual values of water velocity $(\mathrm{m} / \mathrm{s})$ corresponding to the presence (P)/absence (A) of the species O. limosus in SS2, 2011-2013.

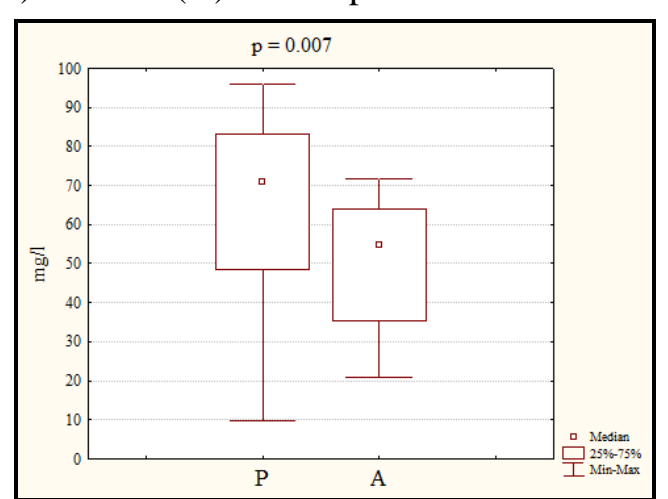

Figure 8a: Box-plots showing the average annual values of calcium (mg/l) corresponding to the presence (P)/absence (A) of the species O. limosus in SS1, 2011-2013.

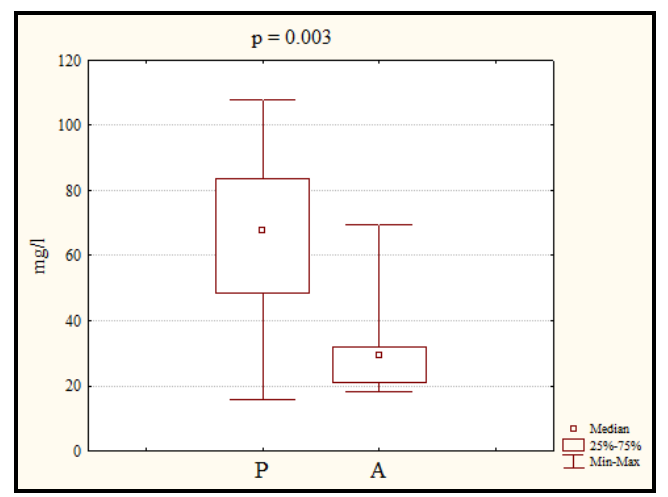

Figure 8b: Box-plots showing the average annual values of calcium (mg/l) corresponding to the presence (P)/absence (A) of the species O. limosus in SS2, 2011-2013.

The $O$. limosus ecological tolerance and also its presence in various habitats (Ortmann, 1906; Aklehnovich and Razlutskij, 2013) can represent a future threat for the ICS (Pârvulescu, 2009; Söderbäck, 1995; Burrič et al., 2009) with the risk of coming into contact with the protected species, among which includes A. torrentium and A. astacus, the former being frequently found in tributaries of the Danube (Pârvulescu and Petrescu, 2010). However, the impact caused by its presence in a small natural ecosystem cannot be predicted accurately, therefore detailed studies are needed. 


\section{CONCLUSIONS}

O. limosus was identified both in the Lower Danube and in the downstream sector of its five studied tributaries.

Results of statistical analyses indicate a preference for deep and warm rivers, and low velocity. A similar pattern was identified for the calcium concentration indicating its preference for high values. 


\section{REFERENCES}

1. Aklehnovich A. and Razlutskij V., 2013 - Distribution and spread of spiny-cheek crayfish Orconectes limosus (Rafinesque, 1817) in Belarus, BioInvasions Records, 2, 3, 221-225.

2. Băcescu M. C., 1967 - The fauna of the S. R. Romania - Crustacea, Decapoda, S. R. Romania Publishing House, Bucharest, 4.

3. Boyer M. C., 1964 - Streamflow measurement, in Chow V. T. (ed.), Handbook of Applied Hydrology, Edit. McGraw-Hill, New York, 15-41.

4. Buřič M., Kouba A. and Kozák P., 2009 - Spring mating period in Orconectes limosus: the reason for movement, Aquatic Science, 71, 473-477.

5. Clavero M., Brotons L., Pons P. and Sol D., 2009 - Prominent role of invasive species in avian biodiversity loss, Biological Conservation, 142, 10, 2043-2049.

6. Diéguez-Uribeondo J., 2006 - The dispersion of the Aphanomyces astaci carrier Pacifastacus leniusculus by humans represents the main cause of disappearance of the indigenous crayfish Austropotamobius pallipes in Navarra, Bulletin Français de la Pêche et de la Pisciculture, 380381, 1303-1312.

7. EC, European Commission, 2008 - Towards an EU strategy on invasive species, http://ec.europa.eu/environment/nature/invasivealien/docs/1ENACTpart1v6.pdf, accessed in March, 2014.

8. EC, European Commission, 2012 - European Commission, DG Environment - LIFE Unit, http://ec.europa.eu/life/, accessed in September, 2012.

9. Galil B. S., 2007 - Loss or gain? Invasive aliens and biodiversity in the Mediterranean Sea, Marine Pollution Bulletin, 55, 7-9, 314-322.

10. Gherardi F., 2006 - Crayfish invading Europe - the case study of Procambarus clarkia, Marine and Freshwater Behaviour and Physiology, 39, 175-191.

11. Holdich D. M., Reynolds J. D., Souty-Grosset C. and Sibley P. J., 2010 - A review of the ever increasing threat to European crayfish from non-indigenous crayfish species, Knowledge and Management of Aquatic Ecosystems, 11, 394-395.

12. Lindqvist O. V. and Huner J. V., 1999 - Life history characteristics of crayfish: what makes some of them good colonizers? in Crayfish in Europe as alien species. How to make the best of a bad situation? Gherardi F. and Holdich D. M. (eds), Rotterdam, Brookfield, http://www.amazon.co.uk/Crayfish-Europe-Alien-Species-Crustacean/dp/9054104694, accessed in May, 2012, 299.

13. McAlpine D., Hogans W. E. and Fletcher T. J., 1991 - Orconectes limosus (Crustacea, Cambaridae) an addition to the crayfish fauna of New Brunswick, Canadian Field-Naturalist, 105, 386-387.

14. MEA, Millennium Ecosystem Assessment, 2012 - http://www.maweb.org/en/index.aspx, accessed in July, 2012.

15. Ortmann A. E., 1906 - The crayfishes of the state of Pennsylvania, Memoirs of the Carnegie Museum, 2, 34.

16. Paaver T. and Hurt M., 2009 - Status and management of noble crayfish Astacus astacus in Estonia, Knowledge and Management of Aquatic Ecosystems, 18, 394-395.

17. Panov V. E., Alexandrov B. and Arbaciauskas K., 2009 - Assessing the risks of aquatic species invasions via European inland waterways: the concepts and environmental indicators, Integrated Environmental Assessment and Management, 5, 110-126.

18. Pârvulescu L., 2009 - Illustrated guide to identify the species of crayfish in Romania, Oradea University Press, Oradea, 28. (in Romanian)

19. Pârvulescu L., Paloş C. and Molnar P., 2009 - First record of the spiny-cheek crayfish Orconectes limosus (Rafinesque, 1817) (Crustacea: Decapoda: Cambaridae) in Romania, NorthWestern Journal of Zoology, 5, 2, 424-428.

20. Pârvulescu L., 2010 - Crayfish field guide of Romania, Edit. Bioflux, Cluj-Napoca, 26. 
21. Pârvulescu L. and Petrescu I., 2010 - The distribution of stone crayfish Austropotamobius torrentium (Schrank, 1803) (Crustacea: Decapoda: Astacidae) in the south-west Romanian mountain and sub-mountain area, Travaux du Museum National d'Histoire Naturelle "Grigore Antipa”, 53, 103-113.

22. Peay S. and Füreder L., 2011 - Two indigenous European crayfish under threat - how can we retain them in aquatic ecosystems for the future? Knowledge and Management of Aquatic Ecosystems, 401, 33.

23. Petrusek A., Filipová L., Duriš Z., Horká I., Kozák P., Policar T., Štambergová M. and Kučera Z., 2006 - Distribution of the invasive spiny-cheek crayfish (Orconectes limosus) in the Czech Republic, Past and present, Bulletin Français de la Pêche et de la Pisciculture, 380-381, 903918.

24. PM, Management plan, 2010 - http://www.pnPorţiledefier.ro/, accessed in March, 2011.

25. Sîrbu I. and Benedek A. M., 2004 - Practical ecology, "Lucian Blaga" University Press, 254. (in Romanian)

26. Souty-Grosset C., Reynolds J. D., Gherardi F., Schulz R., Edsman L., Fureder L., Taugbol T., Noel P., Holdich D., Smietana P., Mannonen A. and Carral J., 2006 - CRAYNET, achievements in scientific management of European crayfish: the way forward and future challenges, Bulletin Français de la Pêche et de la Pisciculture, 380-381, 1395-1405.

27. Söderbäck B., 1995 - Replacement of the native crayfish Astacus astacus by the introduced species Pacifastacus leniusculus in a Swedish lake: possible causes and mechanisms, Freshwater Biology, 33, 291-304.

28. Söderhäll K. and Cerenius L., 1999 - The crayfish plague fungus: history and recent advances, Freshwater Crayfish, 12, 11-35.

29. Ueno M. and Mizuhira V., 1984 - Calcium transport mechanism in crayfish gastrolith epithelium correlated with the molting cycle, Histochemistry, 80, 3, 213-217.

30. Unestam T., 1969 - Resistance to the crayfish plague in some American, Japanese and European crayfishes, Report of the Institute of the Freshwater Research Drottningholm, 49, 202-209. 